\title{
Promyelocyte Count
}

National Cancer Institute

\section{Source}

National Cancer Institute. Promyelocyte Count. NCI Thesaurus. Code C74622.

The determination of the number of promyelocytes present in a sample. 